\section{Sr. Editor,}

Entre as diversas complicações das mulheres com Doença Falciforme (SS, SC e STH), destacamos: abortos espontâneos, natimortos e partos prematuros (1, 2, 3 e 4). Estas não são complicações raras em serviços obstétricos, estando presentes em outras patologias além da Doença Falciforme.

Não é habitual associar-se a presença de abortos, natimortos e partos prematuros em mulheres portadoras de Hemoglobina S (AS).

Em trabalho anterior (5), levantamos a freqüência de antecedentes de abortos, natimortos e partos prematuros ( 7 e 8 meses de gestação) em 14 mulheres com Hemoglobina AS e comparamos com a freqüência apresentada por 263 mulheres com Hemoglobina AA (normais). Os principais resultad os foram - Abortos: AA $=40.3 \%$ e AS $=78.6 \%$ ( significante, $p<0.01$ ); Natimorto: $A A=20.6 \%$ e $A S=28.6 \%$ (não significante); Partos Prematuros: $\mathrm{AA}=6.8 \%$ e AS $=7.1 \%$ (não significante).

Podemos observar que existiu maior freqüência de abortos nas mulheres AS (78.6\%) do que nas AA (40.3\%).

Duchovni-Silva \& Ramalho $(6,7)$ referem que nas gestações de mulheres heterozigotas AS, cujos parceiros foram AA, existiu maior número de gestações a termo de fetos AS, do que de fetos AA e admitem "...a existência de um efeito materno na transmissão hereditária dos traços falciforme e talassêmico beta". Este autores $(6,7)$ também admitem que "....0 abortamento preferencial dos embriões AA pelas mães heterozigotas parece ser a hipótese mais atraente...".

Os achados de Duchovni-Silva \& Ramalho $(6,7)$ vêm de encontro aos nossos resultados (5) porque em um casal quando a mulher é AS e o parceiro é AA a possibilidade da geração de embrião AA e ou AS é semelhante, isto é, 50\%
AA e $50 \%$ AS. Se as mulheres AS tiveram maior número de recém-nascidos AS (6) e encontramos maior freqüência de abortos (5), é provável que os abortos das mulheres AS tenham sido de embriões AA.

Acreditamos que são necessários outros estudos científicos para melhor elucidação destes fatos, em conseqüência da importância médico-social dos portadores da Hemoglobina S.

\section{Referências Bibliográficas}

1. Nascimento, M.L.P.; Cardel, R.C. Complicações da gestação na Anemia Falciforme. Bol. Soc. Bras. Hematol. Hemot. 1996, 18 (Supl): Ref. 025-P.

2. Fiakpui, E.Z. \& Moran, E.M. Pregnancy in sickle hemoglobinopathies. J. Reprod. Med. 1973, 11:28-34.

3. Gonçalves, M.M. \& Ávila, I. Anemia Falciforme e Gravidez - Femina 1985. 13 (1): 23-30.

4. Pantaleão, S.; Nunes Maia, H.G.S.; Paiva, C.S.M.; Medeiros Filho, J.G. Gestational risk of sickle cell disease. J. Bras. Ginec. 1992, 102 (10): 405-417.

5. Nascimento, M.L.P. \& Dumas, A. Transmissoras de Hemoglobina S (AS) e Beta Talassemia Menor: abortos e partos prematuros. Anais do Encontro Norte Nordeste sobre Anemias e Parasitoses, Salvador - Bahia , 1999: 73.

6. Duchovni-Silva, I.; Ramalho, A.S. Maternal segregation distortion in sickle-cell and b-thalassaemia traits? Lancet 1996,347 (9002): 691-2.

7. Duchovni-Silva, I.; Ramalho, A.S. Efeito materno no traço de hemoglobina C. J. Bras. Patol, 2000. 36 (3): 146.

Recebido: $18 / 12 / 2000$

Aceito: 15/01/2001

Maria de Lourdes Pires Nascimento

Fundação para Assistên cia às Anemias e Parasitoses (ANEPA)

Coordenadora do Serviço de Assistência às Anemias Genéticas (SAAG) do Hospital Geral Roberto Santos (HGRS) -

Salvador, Bahia

Consultora Científica dos Programas de Anemias da Universidade do Estado da Bahia (UNEB)

Correspondência: Maria de Lourdes Pires Nascimento

E-mail: mlpnascimento @ e-net.com.br 